\title{
Correction to: Remittances of Immigrant Citizens, Attachment to the Host Country and Transnationalism
}

\section{Nonna Kushnirovich ${ }^{1}$}

Published online: 9 March 2021

(c) Springer Nature B.V. 2021

\section{Correction to: Population Research and Policy Review https://doi.org/10.1007/s11113-020-09630-7}

In the original publication of this article, the corresponding author name was misplaced and publihsed incorrectly. Now the same has been corrected in this Correction.

Publisher's Note Springer Nature remains neutral with regard to jurisdictional claims in published maps and institutional affiliations.

The original article can be found online at https://doi.org/10.1007/s11113-020-09630-7.

Nonna Kushnirovich nonna@ruppin.ac.il

1 Department of Economics and Management, Ruppin Academic Center, Emek, 40250 Hefer, Israel 